\title{
Exploration Of The Implementation Of PKL In Achieving MBKM Goals In Accounting Study Program
}

\author{
Devi Febrianti ${ }^{*}$, Ira Megasyara ${ }^{2}$, Ninik Mas'adah $^{3}$ \\ 1,2,3, Accounting Department, Faculty of Economics dan Business, \\ Universitas Muhammadiyah Lamongan. \\ ${ }^{*}$ Corresponding author: \\ Email: devifebrianti92@gmail.com
}

\begin{abstract}
.
This study aims to determine whether the internship activities that have been carried out by the accounting study program at the Muhammadiyah Lamongan University can help achieve MBKM goals and bring benefits to universities, students, and internship partner agencies. This research was conducted on 10 partner industries in the accounting study program industrial internship program, Faculty of Economics and Business, Muhammadiyah Lamongan University in 2021 spread across the Lamongan area, and 4 students of Accounting study program who had industrial internships that year. Data collection techniques used in this study were Forum Group Discussion $(F G D)$, observation, interviews, and documentation. Partners fully support the industrial internship program. This partner support has an impact on the achievement of MBKM goals where the PKL program or industrial internship can improve the competence of graduates, both soft skills and hard skills so that they are better prepared to meet the needs of the world of work, prepare graduates as future leaders of the nation who have superior and personality, namely providing sufficient experience. to students related to direct learning in the workplace and students can solve problems that exist in the industry which can be considered as a form of learning independence. The results of the study also show that the benefits of this program can also be felt by universities and internship partner agencies. However, based on the results of the evaluation of the accounting department, it has not been fully maximized in implementing the PKL program or industrial internship.
\end{abstract}

Keywords: MBKM Goals, Partner Support, and PKL Implementation.

\section{INTRODUCTION}

Freedom of learning is a policy that has big ideas to give freedom to lecturers and students to carry out the teaching and learning process that is fun and not burdensome. The MBKM policy aims to create an innovative and creative learning culture according to needs through independent, flexible, and not rigid education and teaching. In the regulation of the Menteri Pendidikan dan Kebudayaan to fulfill the period and learning load, it can be done through two activities, namely by following the entire learning process in the study program according to the study period and load and participating in part of the learning process in the study program according to a certain periid and learning load and the rest following outside the program. study either in one faculty, university, or in a related industry. The MBKM program in 
essence also provides challenges and opportunities for students to develop personality, creativity, needs, independence, self-management as a whole by seeking, finding knowledge and experience in the field, whether related to problems of social dynamics, social interaction, cooperation, etc.Universities as institutions that provide learning for students must plan and implement innovative learning processes to encourage students to achieve learning achievement indicators consisting of aspects of attitudes, knowledge, and skills optimally and relevant to the times.

One of the things that can be done is an apprenticeship program (Suprayogi et al., 2021). Field Work Practices (PKL) or commonly called internships are programs that provide students with professional work experience in a structured manner with the help of experts in their fields (Sun, 2014).Permendikbud Nomor 3 Tahun 2020 issued by the Kementerian Pendidikan dan Kebudayaan states that students have the right to study for 3 semesters outside their study program. Apprenticeship is one of eight forms of learning, namely: teaching assistance in education units, fieldwork/internship practices, student exchanges, entrepreneurial activities, humanitarian projects, research, independent project studies, and Community Service Program.Permenaker No. 6 Tahun 2020 ayat 1, states that apprenticeship is a job training in which students will work directly with the supervision of supervisors and instructors or competent workers in the production process of company goods and services to be able to master certain skills. Apprenticeship activities can be carried out based on the personal wishes of students or as a mandatory requirement that students must take in education. Internships are very good for students because during the internship process students will be accompanied by field supervisors who will train and advise so that students can learn the work culture in the industry and can interact with their new environment.

Internships will also teach students new skills in the industry as well as teach how to work. Through internships, students will also realize that what they have learned so far on campus will help prepare their future.Apprenticeship is part of the job training system at the training agency by working directly under the guidance and supervision of instructors or competent workers in the process of producing goods and/or services in the company to master certain skills or expertise. Apprenticeship can be done because of the personal desire of the student or as part of the mandatory requirements that must be taken by students and the assessment is calculated. The internship program not only provides benefits for student interns but also benefits companies that provide opportunities for students (Hayati, 2021). Lerman (2019) states that there are at least five advantages for companies that open internship opportunities and manage them well, namely contributing to production and service costs, reducing the cost of hiring new employees if the company can retain most of the apprentices, reducing training costs for new employees to get to know tools. and work environment, increasing the company's experience in conducting apprenticeship programs and the cost of internships is part of the investment for company development. 
Students will also benefit from the internship program, including competencies in the form of hard skills (skills, analytical skills, complex problem solving, etc.) and soft skills (professional ethics, communication skills, ability to cooperate in groups, etc.) fieldwork (Suprayogi et al., 2021). This program requires coordination and monitoring of supervisors from both campus and internship supervisors because each assignment will be converted with a weight of 20-80 credits and graduate competency standards. Lectures that are usually given in class are now conducted directly at the internship site with the help of the internship supervisor (Hayati, 2021).However, the benefits of industrial internships cannot be obtained optimally for students and companies when the management is not good. Farmaki (2018) states that students will not be able to absorb knowledge from the internship program when the company does not place students according to their expertise even though the dynamics of very fast industrial development requires students to be more flexible in dealing with the world of work. Baert et al. (2021) also mentioned that some companies did not find any benefits from internships. Lerman (2019) states that the benefits of capital investment for internships are very small because many of the students who have carried out internships do not return to the company where they are apprenticed and choose to work in other companies, companies have difficulty weighing the disadvantages or benefits of having an industrial internship.

The accounting study program at the Muhammadiyah Lamongan University has required 4th-semester students to do internships in relevant industries. The internship program in the accounting study program has only been carried out by one batch in the 2020/2021 academic year. The internship/PKL program aims to provide students with the experience to get hands-on learning in the world of work (experiential learning) for one semester. Based on the purpose of the internship as well as some of the benefits obtained by both students and partners that have been described above, it is hoped that this internship program can help Accounting Departmen, Muhammadiyah Lamongan University in achieving the goals of MBKM. Therefore, the implementation of the internship program needs to be evaluated to find out whether the internship activities that have been carried out by the accounting study program at the Muhammadiyah Lamongan University can help achieve MBKM goals and bring benefits to universities, students, and interns partners agencies. The benefit of this research is as a reference and consideration for universities, students, and internship partners in making strategies for implementing internships that will be carried out to achieve MBKM goals. The novelty of this research is to discuss more deeply the impact or benefits of the internship program for students, universities, and internship partners using the focus group discussion (FGD) method and through a direct approach to students through interviews. 


\section{LITERATURE REVIEW \\ Merdeka Belajar Kampus Merdeka (MBKM)}

\section{a. Legal Foundation}

Merdeka Belajar - Kampus merdeka is one of the policies of the Minister of Education and Culture, Nadiem Makariem. One of the programs from the Merdeka Belajar - Kampus Merdeka policy is the Right to Study for Three Semesters Outside the Study Program (Direktorat Jenderal Pendidikan Tinggi Kemdikbud RI, 2020: 4). The program is a mandate from various regulations / legal foundations of higher educationon to improve the quality of learning and higher education graduates. The legal basis for the implementation of the Three Semester Learning Rights Policy program outside the Department, includes the following:

1. Undang-Undang Nomor 20 Tahun 2003, tentang Sistem Pendidikan Nasional.

2. Undang-Undang Nomor 12 Tahun 2012, tentang Pendidikan Tinggi.

3. Undang-Undang Nomor 6 Tahun 2014, tentang Desa.

4. Peraturan Pemerintah Nomor 04 Tahun 2014, tentang Penyelenggaraan Pendidikan Tinggi dan Pengelolaan Perguruan Tinggi.

5. Peraturan Presiden nomor 8 tahun 2012, tentang KKNI.

6. Peraturan Menteri Pendidikan dan Kebudayaan Republik Indonesia Nomor 3 Tahun 2020,tentang Standar Nasional Pendidikan Tinggi.

7. Peraturan Menteri Desa, Pembangunan Daerah Tertingga, dan Transmigrasi Nomor 11 Tahun 2019, tentang Prioritas Penggunaan Dana Desa Tahun 2020.

8. Peraturan Menteri Desa, Pembangunan Daerah Tertinggal, dan Transmigrasi Nomor 16 Tahun 2019, tentang Musyawarah Desa.

9. Peraturan Menteri Desa, Pembangunan Daerah Tertinggal, dan Transmigrasi Nomor 17 Tahun 2019, tentang Pedoman Umum Pembangunan dan Pemberdayaan Masyarakat Desa.

10. Peraturan Menteri Desa, Pembangunan Daerah Tertinggal, dan Transmigrasi Nomor 18 Tahun 2019 , tentang Pedoman Umum Pendampingan Masyarakat Desa

\section{b. Purpose}

In the guidebook published by the Direktorat Jenderal Pendidikan Tinggi Kemdikbud RI, (2020: 4) the objective of the Merdeka Belajar - Kampus Merdeka policy, the program "right to learn three semesters outside the study program " is to improve the competence of graduates, both soft skills and hard skills, so that more prepared and relevant to the needs of the times, preparing graduates as future leaders of the nation with superior and personaliti. Experiential learning programs with flexible pathways are expected to facilitate students to develep their potential according to their passions and talents. Merdeka Belajar - Kampus Merdeka "The Right to Learn Three Semesters Outside the Study Program". 


\section{c. General requirements for Merdeka Belajar - Kampus Merdeka}

\section{Right to Study for Three Semesters Outside the Study Program}

The program "right to study for three semesters outside the study program", which must be fulfilled by universities and students including (Direktorat Jenderal Pendidikan Tinggi Kemdikbud RI, 2020: 4) :

1. Students come from accredited study programs.

2. Active students registered with PDDikti.

\section{d. Implementation}

\section{Role of Related Parties}

a. College

b. Faculty

c. Department

d. Student

\section{Forms of Learning Activities}

Under Permendikbud Nomor 3 Tahun 2020 Pasal 15 ayat 1, forms of learning activities can be carried out within the Study Program and outside the Study Program including:

1. Student Exchange

2. Internship/Work Practice

3. Teaching Assistance in Education Units

4. Research

5. Humanitarian Project

6. Entrepreneurial Activities

7. Study/Independent Project

8. Building a Village / KKN

\section{Field Work Practice/Internship}

According to Pratama et al. (2017) Praktik Kerja Lapangan (PKL) is a form of systematic and synchronous implementation between educational programs on campus and mastery of skills programs obtained through work activities directly in the world of work to achieve a certain level of expertise. Hardie et al. (2018) state that Internships are becoming more relevant to universities because they provide students with practical skills that can align with their career aspirations.

The Direktorat Jenderal Pendidikan Tinggi Kemdikbud RI (2020: 4) stated that there are six objectives of the internship program, including:

1. Internship program 1-2 semesters, providing sufficient experience to students, direct learning in the workplace (experiential learning).

2. Students will gain hard skills (skills, complex problem solving, analytical skills, etc.), as well as soft skills (professional/work ethics, communication, collaboration, etc.).

3. Industries get talent that, if suitable, can be recruited immediately, thereby reducing recruitment and initial training/induction costs. 
4. Students who are familiar with the workplace will be more stable in entering the world of work and careers.

5. Through this activity, industrial problems will flow to universities so that updating teaching and learning materials for lecturers and research topics in universities will be more relevant.

6. Learning activities carried out in collaboration with partners include companies, non-profit foundations, multilateral organizations, government institutions, and start-ups.

According to Petrillose and Montgomery, (1997) in Hardie et al. (2018) the purpose of the internship program is to provide opportunities for students to acquire knowledge and skills that are not easily taught in a classroom environment, such as interpersonal skills and the ability to apply concepts theoretical to real-world situations. To do this, educators must be aware of industry needs and must be willing to provide the industry with quality, competent individuals upon graduation.Feijoo et al. (2019) also stated that industrial internships are also beneficial for students in recognizing the world of work and can improve their skills and level of professionalism. This is due to their increased ability to apply the knowledge they gain in college into practice, learn to make decisions, improve their ability to work in teams, and adapt to new environments. In addition, positive feedback from partners can be used by universities to make changes to curriculum content based on the evaluation of internship results and mentor assessments.

In addition, it is not only interns who feel the impact of the program, but companies can also feel the benefits. Lerman (2019) states that there are at least five advantages for companies that open internship opportunities and manage them well, namely contributing to production and service costs, reducing the cost of hiring new employees if the company can retain most of the apprentices, reducing training costs for new employees to get to know tools. and work environment, increasing the company's experience in conducting apprenticeship programs and the cost of internships is part of the investment for company development. Kukreti \& Dani (2021) also state that internships can benefit university students and especially companies. This is because the existence of internship activities can help ease the work of the company and as an investment effort by the company in recruiting employees of interest-based on the aspect of the ability of interns to improve their skills and professionalism while working. Kukreti \& Dani (2021) also stated that twelve percent of student internships at the company would have a higher chance of being accepted to work in an internship company.

\section{Previous Research}

Fuadi \& Aswita (2021) conducted a study entitled Merdeka Belajar Kampus Merdeka (MBKM): How to Apply and Constraints Faced by Private Universities in Aceh using literature studies and interviews. Through the literature study, private universities have implemented several programs, including student exchange 
programs between study programs within universities and student exchanges with study programs outside universities, as well as teaching programs in educational institutions and internships assisted by ministry funds. The challenges faced by private universities in implementing the independent campus learning program include; 1) the process of adapting the KKNI curriculum to the MBKM program, 2) partner campuses that are still limited, 3) collaboration of private universities in Aceh with outside parties, both companies, BUMN, BUMD, and even the government is still very limited, 4) fund management by foundations that have not budgeted funds for MBKM, 5) quality and productivity of human resources for lecturers and students.

Puspitasari \& Nugroho (2021) conducted a study entitled Implementasi Kebijakan Merdeka Belajar, Kampus Merdeka Fisip UPN Veteran Jawa Timur. This study uses a qualitative research method approach and the type of research is descriptive, by conducting interviews with parties who are directly related to MBKM policies at UPNVJT. The results of the study state that the MBKM policy is less effective and has not been implemented properly. So the implementation of the MBKM policy is not fully implemented effectively previous research.Meanwhile, Fatah (2021) conducted research entitled Eksplorasi Dukungan Industri Mitra Dalam Pelaksanaan Magang Pada Program Merdeka Belajar Kampus Merdeka.This research is a qualitative descriptive study. Data collection techniques used are Forum Discussion Group (FGD), observation, and documentation. And data analysis was done descriptively. The results of the study indicate that in the planning stage of the MBKM internship, partner industries have been involved in mapping the number of students who can implement the program.

The partner industry also offers several models of apprenticeship forms according to partner conditions as well as evaluation models that can optimize the implementation of internships. In the internship implementation stage, partner industries support students to carry out industrial practices according to their fields of interest and provide opportunities for participants to analyze partner industry deficiencies and find solutions and apply the solutions offered directly to the field.Hayati (2021) conducted a study on the Evaluasi Peserta Magang Di Instansi Pemerintahan Dengan Metode Bekerja Di Rumah (Studi Kualitatif sebagai Persiapan Magang Merdeka Belajar Kampus Merdeka). The research was followed up with focus group discussion interviews. The results of the study concluded that internships during the pandemic and unpaid can still run effectively and efficiently, judging from the benefits felt by universities, students, and internship partner agencies.

\section{METHODS}

This article uses a descriptive qualitative approach. Qualitative research is research that uses descriptive data in the form of written and spoken words based on the actors or objects inhabited (Fitrah \& Luthfiyah, 2018:43). While this type of 
research is descriptive by trying to describe much more deeply the activities of street vendors/apprentices in achieving MBKM goals and the impact or benefits for universities, students, and interns partner agencies. This research is qualitative descriptive research. This research was conducted on 10 partner industries in the accounting study program industrial internship program, Faculty of Economics and Business, the Muhammadiyah Lamongan University in 2021 spread across the Lamongan area, and 4 students of Accounting study program who did industrial internships that year. Data collection techniques used in this study were Forum Group Discussion (FGD), observation, interviews, and documentation. This research uses descriptive analysis. While the data processing technique uses the technique of Miles and Huberman (1992:20) in et al (2014), as follows:

1) data reduction;

2) data display

3) conclusion drawing/verification.

\section{RESULT AND DISCUSSION}

Industrial Partners and Student Responses to the Implementation of PKL or Industrial Internships

PKL or industrial internships in the Accounting Department at Muhammadiyah Lamongan University are held for 1 month, namely on August 4, 2021 - November 4, 2021. The following is the distribution of partner industries and students on industrial internships on August 4, 2021:

Table 1. Distribution of Partner Industries and Students of Accounting Study Program

\begin{tabular}{clcc}
\hline No & \multicolumn{1}{c}{ Partner } & Total & Percentage \\
1. & KSPPS Bina Syari'ah Ummah & 1 & $0,071 \%$ \\
2. & Kecamatan Ngraho & 1 & $0,071 \%$ \\
3. & RSU Muhammadiyah Babat & 2 & $0,14 \%$ \\
4. & KSPPS BMT NU ngasem cabang kota & 1 & $0,071 \%$ \\
5. & Perumda Aneka Usaha Lamongan Jaya & 2 & $0,14 \%$ \\
6. & KSPPS BMT UAS sumberrejo & 1 & $0,071 \%$ \\
7. & KSPPS BMT Surya Raharja cabang & 2 & $0,14 \%$ \\
8. & maduran PLN (Persero) Rayon Jatirogo & 1 & $0,071 \%$ \\
9. & BMT Mandiri Sejahtera Cabang & 2 & $0,14 \%$ \\
& Kedungpring & & $0,071 \%$ \\
10. & Balai Desa Baureno & 1 &
\end{tabular}

Based on FGD activities, data was obtained that $100 \%$ of partners welcomed the industrial internship conducted by students of the Accounting Department, Faculty of Economics and Business, Muhammadiyah Malang University. Here are some responses from partners on the industrial internship program: 
a. One month of internship time is sufficient time for students to recognize the work environment and adapt.

b. The existence of an industrial internship program can have a good impact on students in improving not only hard skills but also soft skills they will acquire.

c. The industrial internship program can provide the best picture for students about the work environment which can later improve their work ethic and ability to work in teams.

d. The duration of the industrial internship is considered sufficient for students to carry out work independently.

e. This duration is also considered sufficient for partner mentors in assessing student internships.

Sejahtera Kedungpring Branch who stated that the duration of the one-month internship was insufficient for students to deepen their understanding of the work environment. Partner industries feel that the lack of internship time will lead to less than optimal implementation and the lack of knowledge that students should acquire during internships. On the other hand, the results of interviews with 4 students of the Accounting Department at the Muhammadiyah Lmaongan University, namely Indah, Rizky, Serly, and Prita, stated that the PKL or industrial internship program was running optimally because of the large amount of knowledge they gained when doing industrial internships. The following is Rizky's statement regarding industrial internships:

"I think it's quite optimal because after implementing street vendors, I feel like I have new skills and experiences that I couldn't get on campus so far. In addition, there are many experiences that I gained during the implementation of street vendors such as how to make decisions when problems occur and also how to solve them. How to work with a team. How do we behave when we face many people who of course have different characters and traits and many more."

The student's statement above implies that with an industrial internship, students also get benefits, namely experience in understanding the world of work and improving their skills. This implies that the industrial internship program is running optimally. This is in accordance with the statement of Suprayogi et al. (2021) and Feijoo et al. (2019) which states that students will also benefit from the internship program, including recognizing the world of work, competencies in the form of hardskills (skills, complex problem solving, analytical skills, etc.) and softskills (professional ethics, communication skills, teamwork skills, etc.) during internships/field work practices.

Meanwhile, the student of the Accounting Department, Indah stated:

"In the implementation of these street vendors activities running optimally, students can work well according to the existing soup, students also do not have significant obstacles in working. In addition, students also completed the street vendors report quite well." 
Based on the statement above, there is an implied message that the implementation of street vendors or industrial internships is running optimally. This is evidenced by the ability of students to do a good job and the ability of students to find solutions to problems that arise during industrial internships. According to Hayati (2021) internships during a pandemic can still run effectively and efficiently, judging by the benefits felt by students and partners.

\section{Partner Support on the Implementation of PKL or Industrial Internships}

Based on FGD activities, data was obtained that partners expressed their support for industrial internship activities carried out by students of the Accounting Department, Faculty of Economics and Business, Muhammadiyah Lamongan University. Here are some partner support for industrial internship programs:

a. Partners provide internship students with related knowledge before being given independent assignments so that interns have a brief overview of the company where they are interning.

b. Partners explains the process of making financial reports to internship students starting from transactions until financial reports are complete.

c. Partners also offer jobs that match the interests, talents and majors of the interns so that industrial internships run optimally.

d. Partners are very open about the information needed by interns so that they can develop their knowledge according to their interests and majors. Interns are also allowed to ask questions or to consult regarding problems encountered during industrial internships.

The results of the FGD above are following the opinion of the internship students who stated that students had been provided with certain knowledge in identifying the company where the internship was before being given a job. The following is a statement from Prita:

"In its implementation, it is carried out with certain briefings, for students who aim to do internships in a workplace, both in the business world and in the industrial world, at least they are provided with field supervisors first so that they are better prepared when they are given assignments. The field supervisor also provides specific information related to the tasks to be given, such as how to make financial reports."

The statement above implies that interns have been provided with special knowledge before being given assignments. This can help students identify the company where they are interning and also in solving cases that will be resolved in the process of working on their work. In addition, this information can provide an overview for interns in understanding the work of an accountant, especially in making real financial reports that interns have not received before. By the Direktorat Jenderal Pendidikan Tinggi Kemdikbud RI (2020:5) states that one of the objectives of the internship program is to provide students with sufficient experience, direct learning in the workplace(experiential learning).. 
Rizky also stated that the partner's support could be felt from him starting the internship until the internship was completed, as follows:

"I think the company or partner is very supportive, this can be seen from when students apply to student companies that have been received well, partners at the company also patiently direct students to be able to solve existing problems until the release of company partners also provide a sign of farewell which of course is very memorable and cannot be forgotten by students."

Serly stated that partner support can be felt until the internship is completed by providing opportunities to work in internships, as follows:

"They are very supportive and well-received, they even support us so that we can work there because we already know a little bit about working there".

The two student statements above imply that the support provided by partners is not only at the beginning of the internship but until the internship is complete. This is indicated by the good acceptance at the beginning of the internship by partners and the giving of farewell signs to students in commemorating the internship activities at the company. In addition, partners also provide support by providing opportunities for students to be able to work there. Kukreti and Dani (2021) state that internships are an investment effort by the company in recruiting interested employees based on the aspects of the interns' ability to improve their skills and professionalism while working and because of their sufficient knowledge related to the company. So that the company will support interns who have done internships in their company to become employees according to the company's needs. Following the Direktorat Jenderal Pendidikan Tinggi Kemdikbud RI (2020: 5) states that one of the objectives of the internship program is for the industry to get talent which, if suitable, can be recruited immediately, which can be considered as an investment.

Partner Support in the Implementation of PKL or Industrial Internships in Achieving MKBKM Goals

The results of the FGD and interviews in the implementation of PKL/industrial internships conducted by students of the Accounting Department at the Muhammadiyah Malang University obtained information that the support of industrial partners for the implementation of internships in achieving the objectives of the MBKM program is as follows:

a. Carry out PKL/Industrial internship activities following Partner Industry SOPs

b. Provide opportunities for students to study according to their respective fields

c. Provide opportunities for students to have opinions in the implementation of street vendors/industrial internships

d. Carry out daily activities in partner industries with assistance

e. Helping each other in the implementation of street vendors/industrial internships between supervisors and students 
By the results of interviews conducted by researchers to students of the accounting study program at the University of Muhammadiyah Lamongan, namely Indah, Rizky, Serly, and Prita. They stated that the partners' support in implementing street vendors to achieve MBKM's goals was very good because they learned according to their field and they were allowed to gain new knowledge apart from their field. The following is a statement from Prita's:

"The concept at the student internship was previously asked about the student's major so that the supervisor at the internship place knew the student was the right place to apply the knowledge gained during college and to be applied in the internship."

Indah stated that in the implementation of street vendors the partners placed according to their fields, the following is her statement:

"The partner industry provides good facilities when carrying out street vendors. The partner industry provides the information needed by students to make it easier for students to work. And placing students according to their fields "

Prita and Indah's statement shows that partners have shown support in achieving MBKM's goals, namely conducting direct learning in the workplace according to their fields so that students gain new knowledge to improve graduate competencies. According to the Direktorat Jenderal Pendidikan Tinggi Kemdikbud RI (2020: 4) the goal of Merdeka Belajar - Kampus Merdeka policy, the program

"right to learn three semesters outside the study program"

is to improve the competence of graduates, both soft skills and hard skills, to be more prepared and relevant to the needs of the times, preparing graduates as future leaders of the nation with superior and personality, namely providing sufficient experience to students, direct learning in the workplace (experiential learning). Fatah (2021) states that the participation and support of company leaders and field supervisors are very necessary starting from the planning, implementation to program evaluation stages.

Meanwhile, Rizky, a student of the accounting department, stated:

"The concept is like a permanent employee. But I was given the freedom to ask questions and have opinions so that I felt more comfortable and could carry out work easily and during the implementation of street vendors I gained experience such as how to make decisions when problems occur and also how to solve them. How to work with a team. How do we behave when we face many people who of course have different characters and traits and much more"

Risky's statement is certainly a good thing for increasing students' abilities in carrying out problem-solving in their environment. Ismail (2018) states that interns need to be given autonomy to make decisions and self-reflection in order to know their achievements. Participants also need to be supported to focus on completing a job that is their responsibility. This shows that partners support one of the objectives of the internship program according to the Direktorat Jenderal Pendidikan Tinggi Kemdikbud 
RI (2020: 11) where the purpose of the internship program is that students who are familiar with the workplace will be more confident in entering the world of work and careers.

\section{Evaluation of the Implementation of PKL or Industrial Internships for MBKM-Based Curriculum Development}

The FGD activities carried out obtained evaluation results in the implementation of the PKL accounting department at the Muhammadiyah Lamongan University. The following are some evaluations of the implementation of street vendors with partners, namely:

a. The implementation schedule that should have been scheduled in such a way that it produces maximum output

b. Students must understand the basics of using MS. Office

c. Provide briefing before carrying out PKL activities

From some of the evaluations above during FGD activities, it can be seen that the accounting study program at the Muhammadiyah Lamongan University experienced several obstacles in implementing the PKL program even though the accounting study program was able to implement one of the lessons that referred to Ppada Permendikbud No. 3 Tahun 2020 Pasal 15 Ayat 1, namely internship or work practice.

Under the results of an interview with Indah, a student of the accounting study program at the University of Muhammadiyah Lamongan who stated:

"It is better to be prepared carefully so that students can also find internships properly without being in a hurry so that in the future students can run the street vendors program smoothly"

Not only Indah, but also Serly agrees. Here's his statement:

"It is better if the PKL program is directed further ahead of time so that students are not confused and students can also better prepare themselves for PKL and it is better to do it more in 1 month so that we can master the fields where they are placed at the agency"

The statement above is in accordance with the statement of Puspitasari \& Nugroho (2021) which states that there are many programs and activities that must be carried out quickly, making it difficult for implementers to implement MBKM programs and activities. This makes the accounting study program not ready to carry out the street vendors program. Readiness can be affected by several things. According to Puspitasari \& Nugroho (2021)there is 3 strategic readiness that needs to be observed for successful implementation, namely: Organizational, human, and environmental. Organizational readiness with regard to issues: 1) Whether the organization has a sufficient mandate to implement the policy. 2) Does the organization have sufficient resources for implementation, both from the structure, system, human and financial. 3) whether the organization already has an implementation plan and adequate implementation infrastructure within the organization, which includes a roadmap, 
work-plan, including "who does what, when, where, and how." Human readiness is related to: 1) Are organizational leaders capable of leading the implementation, both in terms of leadership qualities related to vision, values, and courage, as well as in terms of skills, how to move people within the organization and outside the organization. 2) Do human resources in the organization have sufficient knowledge, skills, and motivation to become policy implementers. Environmental readiness relates to two things, namely: 1) whether the community environment where the policy will be implemented is ready to accept implementation. 2) Is the environment of the government organization in which the policy will be implemented is ready to become an implementation partner.

The explanation above can be applied in the accounting study program in preparing PKL learning activities before they are implemented so that the output results obtained are optimal and students get sufficient provisions in carrying out PKL learning activities.

\section{CONCLUSION}

The Accounting Department at Muhammadiyah Lamongan University has implemented the MBKM program, namely PKL or industrial internships following Permendikbud Nomor 3 Tahun 2020 tentang Standar Nasional Pendidikan Tinggi. Partners fully support the industrial internship program. This partner support has an impact on the achievement of MBKM goals where the PKL program or industrial internship can improve the competence of graduates, both soft skills and hard skills so that they are better prepared to meet the needs of the world of work, prepare graduates as future leaders of the nation with superior and personality, namely providing sufficient experience to students related to direct learning in the workplace and students can solve problems that exist in the industry which can be considered as a form of learning independence. The results of the study also show that the benefits of this program can also be felt by universities and internship partner agencies. However, based on the results of the evaluation of the accounting study program, it has not been fully maximized in implementing the PKL program or industrial internship. The obstacle faced by the accounting study program is in preparing the PKL or internship program which seems sudden so that students are not ready to go into the field with the provisions that are felt to be lacking.

\section{ACKNOWLEDGEMENT}

For this publication, the authors would like to thank the Ditjen Dikti Ristek for funding the research program for Kebijakan Merdeka Belajar Kampus Merdeka and Community Service based on research results and PTS prototypes for the 2021 Fiscal Year. We do not forget to express our gratitude to the Muhammadiyah Lamongan University and our colleagues in the Accounting Department for their support in the process of compiling this research. 


\section{REFERENCES}

[1] Baert,B. S., Neyt, B., Siedler, T., Tobback, I., \& Verhaest, D. (2021). Student internships and employment opportunities after graduation: A field experiment. Economics of Education Review, 83, 1-11. https://doi.org/10.1016/j.econedurev.2021.102141

[2] Farmaki, A. (2018). Tourism and hospitality internships: A prologue to career intentions? Journal of Hospitality, Leisure, Sport and Tourism Education, 23(June), 50-58. https://doi.org/10.1016/j.jhlste.2018.06.002

[3] Fatah, A. (2021). Eksplorasi Dukungan IndustriMitra Dalam Pelaksanaan Magang Pada Program Merdeka Belajar Kampus Merdeka. Seminar Nasional Teknologi Pembelajaran, 283-290. https://snastep.com/proceeding/index.php/snastep/article/view/62

[4] Feijoo, G., Arce, A., Bello, P., Carballa, M., Freire, M. S., Garrido, J. M., Gómez-Díaz, D., González-Álvarez, J., González-García, S., Mauricio, M., Méndez, R., Moreira, M. T., Mosquera-Corral, A., Navaza, J. M., Palacios, M. C., Roca, E., Rodil, E., Rodríguez, H., Rodríguez, O., ... Moreira, R. (2019). Potential Impact On The Recruitment Of Chemical Engineering Graduates Due To The Industrial Internship. Education for Chemical Engineers, 26, 107-113. https://doi.org/10.1016/j.ece.2018.08.004

[5] Fitrah, M., \& Luthfiyah. (2018). Metodologi Penelitian Kulaitatif (Penelitian Kualitatif, Tindakan Kelas, dan Studi Kasus). CV Jejak.

[6] Fuadi, T. M., \& Aswita, D. (2021). Merdeka Belajar Kampus Merdeka (Mbkm): Bagaimana Penerapan Dan Kedala Yang Dihadapi Oleh Perguruan Tinggi Swasta Di Aceh. Jurnal Dedikasi Pendidikan,

5(2), 603-614. http://jurnal.abulyatama.ac.id/index.php/dedikasi

[7] Hardie, G., Almeida, S., \& Ross, P. J. (2018). Value of industry mentoring and resource commitment to the success of an undergraduate internship program: A case study from an Australian university. International Journal of Work-Integrated Learning, 19(2), 155168.

[8] Hayati. (2021). Evaluasi Peserta Magang di Instansi Pemerintahan dengan Metode Bekerja di Rumah. JP3SDM, 10(2), 54-71.

[9] Kukreti, R., \& Dani, R. (2021). Determining the role of working environment, contextual factors and task characteristics in internship satisfaction of hospitality undergraduates. Materials Today: Proceedings, 46(xxxx),

11226-11229. https://doi.org/10.1016/j.matpr.2021.02.514

[10] Lerman, R. (2019). Do firms benefit from apprenticeship investments? IZA World of Labor, October, 1-11. https://doi.org/10.15185/izawol.55.v2

[11] Peraturan Menteri Pendidikan Dan Kebudayaan Nomor 03 Tahun 2020 Tentang Standar Nasional Perguruan Tinggi.

[12] Permenaker No. 6 Tahun 2020 tentang Penyelenggaraan Pemagangan di Dalam Negeri.

[13] Pratama, I. G. N. W., Putra, I. G. . A. C., \& Datya, A. I. (2017). SSistem Informasi Manajemen Praktek Kerja Lapangan Berbasis Website (Studi Kasus Program Studi Sistem Informasi Universitas Dhyana Pura Bali). Jurnal Teknologi Informasi Dan Komputer, 3(1), 342-351.

[14] Puspitasari, R., \& Nugroho, R. (2021). Implementasi Kebijakan Merdeka Belajar, Kampus Merdeka FISIP UPN Veteran Jawa Timur. Dinamika Governance, 11(2), 276292.

[15] Direktorat Jenderal Pendidikan Tinggi Kemdikbud RI. (2020). Buku Panduan Merdeka 
Belajar - Kampus Merdeka. https://doi.org/10.31219/osf.io/ujmte

[16] Sun, C. 10 B. of S. an I. P. E. R. (2014). 10 Benefits of Starting an Internship Program. Employer Resources. http://www.internships.com/employer/resources/setup/benefits

[17] Suprayogi, N., Istanti, Y., Arundina, T., Samidi, S., Hayati, Nasution, Atiqoh Permata, A., Azzam, A. N. G. A., \& Nurmillah, S. (2021). Panduan Pelaksanaan Magang/Praktek Kerja di Sektor Ekonomi dan Keuangan Syariah dalam Mendukung Merdeka Belajar: Kampus Merdeka. 